\title{
Upscaling the Cymbopogon citratus (lemongrass) Extraction Process to Obtain Optimum Alpha-glucosidase Inhibitor (AGI) Levels
}

\author{
Diah Indriani Widiputri ${ }^{1}$, Ivana Julisantika ${ }^{1}$, Irvan S. Kartawiria ${ }^{1}$, Maria DPT Gunawan- \\ Puteri $^{1}$, Florence Ignatia ${ }^{1}$ \\ ${ }^{1}$ Swiss German University, The Prominence Tower, Jl. Jalur Sutera Barat No.15, Alam Sutera, Tangerang, \\ 15143, Indonesia
}

\begin{abstract}
Cymbopogon citratus (lemongrass) has a great potential to be commercialized as an antidiabetic medication due to its alpha glucosidase inhibitor (AGI) activity. To achieve this goal, this paper continues the study of extraction optimization at the pilot scale to determine the effect of sample quantities on AGI activity. This experiment comprised three phases: designing the percolator, optimizing the process parameters and conditions, and determining the correlation between various sample quantities and AGI activity. The effects of macerating the plant material prior to percolation and using different solvent flow rates during extraction were observed. Four different variations were used in the extraction process trials: $63.09 \mathrm{~cm}^{3} \mathrm{~s}^{-1}, 94.64 \mathrm{~cm}^{3} \mathrm{~s}^{-1}, 126.20$ $\mathrm{cm}^{3} \mathrm{~s}^{-1}$, and $189.30 \mathrm{~cm}^{3} \mathrm{~s}^{-1}$. Sample quantities of $400 \mathrm{~g}$ and $500 \mathrm{~g}$ were used to upscale the analysis. The results showed that maceration did not significantly increase AGI activity $(P<0.17)$, but it did shorten the time needed to reach equilibrium concentration. Similarly, the solvent flow rate variations did not affect AGI activity $(P<0.078)$, but they shortened the extraction time. A significant decrease in AGI activities was observed when switching from laboratory to pilot scale, and an even greater decrease in AGI activity was observed when the sample quantity was increased to pilot scale. It was therefore concluded that lemongrass extract can only be used to maintain optimal AGI activity at the maximum sample quantity of $300 \mathrm{~g}$ for the percolator designed in this research, which produced an extraction yield of $39.45 \pm 1.59 \%$.
\end{abstract}

Keywords: Alpha-glucosidase inhibitor; Cymbopogon citratus; Diabetes; Lemongrass; Upscaling extraction

\section{Introduction}

Diabetes mellitus, commonly known as diabetes, is a metabolic disease in which a person's body does not produce insulin or respond to insulin, causing hyperglycemia or high concentrations of blood glucose (Jones et al., 2012). If not treated, diabetes can cause blindness, kidney failure, and cardiovascular disease (Institute for Quality and Efficiency in Health Care, 2018). According to the World Health Organization (WHO), diabetes caused 1.6 million deaths in 2016 (WHO, 2018). Synthetic medications are available to treat diabetes; however, according to Basu et al. (2019), by 2030 treating diabetes could become a serious problem due to both the limited amount of insulin available and poor access, defined as the availability and affordability of diabetic medications in middle- and lowincome countries such as Indonesia (Chow et al., 2018). In order to solve this problem, 
alternatives such as plant-based medications have gained popularity due to their availability and fewer side effects. Many technologies have been developed to increase plants' therapeutic properties (Suryanegara et al., 2015; Zhou et al., 2017) in order to promote diabetic patients' awareness of self-monitoring and self-control of their blood sugar level (Dewi et al., 2017), including plant-based-medications.

Plants such as Cymbopogon citratus (lemongrass), commonly known as serai in Indonesia, have anti-diabetic properties due to the presence of bioactive compounds in their aqueous extract that act as an $\alpha$ - (alpha-)glucosidase inhibitor (AGI) (Adiyoga et al., 2015). Alpha-glucosidase is an enzyme located in the epithelium of the small intestine that breaks down oligosaccharides and polysaccharides to monosaccharides such as glucose. Inhibiting $\alpha$-glucosidase thus reduces the production of glucose and slows down the absorption of glucose into the bloodstream, thereby preventing hyperglycemia (Kumar et al., 2011; Kang et al., 2013).

Despite its scientifically proven anti-diabetic benefits, the commercialization of $C$. citratus has not been explored in depth. At present its commercial value lies primarily in its lemony tang, which is used as flavoring agent and fragrance (Widiputri et al., 2019). It is thus of interest to further explore how the anti-diabetic benefits of $C$. citratus in aqueous extract can be commercialized. Several studies have already been conducted to investigate how to commercialize $C$. citratus as an anti-diabetic therapy. These studies were conducted on a laboratory scale in order to determine the optimum extraction parameters and the most suitable pre-treatments for $C$. citratus, adapted from the industrial-scale process. The optimum extraction conditions suggested were using a fresh-herb-to-aqueous-solvent ratio of $3: 10(\mathrm{w} / \mathrm{w})$ at $70^{\circ} \mathrm{C}$, subjecting it to a pre-treatment process that includes washing it once and drying it in an oven at $40^{\circ} \mathrm{C}$, and subjecting it to extraction for 40 minutes (GunawanPuteri et al., 2016; Widiputri et al., 2017).

Even though laboratory-scale optimization has been conducted, direct commercialization is not possible because the laboratory process may have other parameters that are overlooked and could cause significant problems when the scale is increased. This can increase the risk of commercial failure. It is therefore important to optimize the extraction process on a pilot scale first, utilizing a typical industrial extractor (percolator) to identify which parameters affect the process and to further study the effect of upscaling the AGI activity of lemongrass extract.

\section{Methods}

This study was divided into three stages: designing the percolator, optimizing the percolation equipment parameters, and studying the effect of upscaling the sample quantity to optimize its AGI activity in aqueous extract. All of the results were analyzed based on their extraction yield (grams soluble solids/grams dried lemongrass sample) and AGI activity.

\subsection{Extraction Method}

The solvent and the method of extraction used are known to affect the yield of a bioactive compound (Rahman et al., 2013; Mulia et al., 2015; Khalili et al., 2016). The extraction process used in this study was adapted from previous studies with several modifications. The extraction used a dried sample-to-solvent (water) ratio of 1:20 (w/w), a temperature of $70^{\circ} \mathrm{C}$, a single washing of fresh lemongrass prior to drying, drying in an air dryer for 28 hours, and 70 minutes of extraction time (Gunawan-Puteri et al., 2016; Widiputri et al., 2017).

The first optimization was done by testing the addition of 1 hour of maceration prior to the percolation itself at a constant solvent flow rate. The effect of using different flow rates of the solvent circulating in the percolator was then studied. The flow rate variations 
$\left(63.09 \mathrm{~cm}^{3} \mathrm{~s}^{-1}, 94.64 \mathrm{~cm}^{3} \mathrm{~s}^{-1}, 126.20 \mathrm{~cm}^{3} \mathrm{~s}^{-1}\right.$, and $189.30 \mathrm{~cm}^{3} \mathrm{~s}^{-1}$ ) were determined based on the capacity of the pump used in the percolator system. For this first stage of the experiment, the sample quantity of lemongrass used was $300 \mathrm{~g}$. During the optimization process, the extraction yield obtained from this optimized laboratory maceration extraction method was used as a baseline to ensure that the percolator achieved the same performance with each variation of the method.

Once the optimum parameters were identified, the sample quantity was increased from 300 to $400 \mathrm{~g}$, and finally to $500 \mathrm{~g}$. The upscaled method utilized the same circulation number approach where the circulation number obtained from the experiment using $300 \mathrm{~g}$ was used to compute the extraction times and the theoretical equilibrium times required for 400 and $500 \mathrm{~g}$ samples. The effect of each such variation on the lemongrass' AGI activity was then analyzed.

The method of quantifying the extraction yield was based on the total soluble solids obtained through the oven drying method for final quantification and the utilization of a refractometer to quantify the amount of these solids periodically during the extraction period.

\subsection{The AGI Assay Procedure}

The method used for the AGI assay was adapted and modified from Santoso et al. (2018). Phosphate buffer solution ( $\mathrm{pH} 7$ ), Tris-HCl ( $\mathrm{pH} \mathrm{9)} \mathrm{2M,} \mathrm{sucrose} \mathrm{(56} \mathrm{mM)} \mathrm{in}$ phosphate buffer solution, EDTA (5 mM) in phosphate buffer, and DMSO (50\%) were prepared. The enzyme was first extracted by placing EDTA $(5 \mathrm{mM})$ in phosphate buffer solution in an ice bath at a ratio of $1: 20(\mathrm{w} / \mathrm{v})$ in grams and milliliters and grinding it with mortar and pestle. The enzyme was mixed until it was homogenous, and centrifuged for 1 hour at $4^{\circ} \mathrm{C}$ at $6,000 \mathrm{rpm}$. If the solution was found to have not fully separated, it was centrifuged for a further 30 minutes or more if necessary. The supernatant was then stored in a refrigerator.

Four test tubes were prepared for AGI quantification: a positive control, a control blank, a sample, and a sample blank. Two hundred $\mu \mathrm{L}$ sucrose solution was added to the sample and the positive control, while $400 \mu \mathrm{L}$ was added to the sample blank and the control blank; $100 \mu \mathrm{L}$ of the sample extract diluted in 50\% DMSO at a 1:1 (v/v) ratio was then added to the sample and the sample blank; and $100 \mu \mathrm{L}$ of $50 \%$ DMSO was added to the positive control and control blank. The solutions were vortexed, $200 \mu \mathrm{L}$ of enzyme solution was added to the sample and the positive control, and both were incubated for 20 minutes in a $37^{\circ} \mathrm{C}$ water bath. After incubation, $750 \mu \mathrm{L}$ of the Tris- $\mathrm{HCl} \mathrm{pH} 9$ solution was added to each of the test tubes and the vortex. Using a pipette, the solutions were then filtered through $\pm 1.5 \mathrm{~cm}$ of aluminum oxide powder. Fifty $\mu \mathrm{L}$ each of the filtered solutions were then transferred into 96-well microplate, and $200 \mu \mathrm{L}$ of glucose assay kit was added. The solution was then incubated in an incubator at $37^{\circ} \mathrm{C}$ for 10 minutes. The microplate reader was then used to read the absorbance of the solution at $492 \mathrm{~nm}$ and the AGI percentage was computed using Equation 1 below:

$$
\% \text { Inhibition }=\frac{\left(\left(A_{\text {control }}-A_{\text {control blank }}\right)-\left(A_{\text {sample }}-A_{\text {sample blank }}\right)\right)}{\left(A_{\text {control }}-A_{\text {control blank }}\right)} \times 100 \%
$$

where A stands for absorbance. 


\section{Results and Discussion}

\subsection{Percolator Equipment Design}

The percolator was designed to have a capacity of $13 \mathrm{~L}$ because a pilot-scale reactor is usually between 1 and $100 \mathrm{~L}$ in size. The conical shape was chosen to prevent blockages caused by the plant matter swelling and to allow the involuntary flow of the solvent to the outlet (Balakrishna et al., 2016). The percolator's size was then determined by using the ideal 1:5 diameter-to-height ratio (Cechinel-Filho, 2012), resulting in a dimension of $15.03 \mathrm{~cm}$ in diameter and $75.15 \mathrm{~cm}$ in height. The complete device is illustrated in Figure 1.

The percolator was designed on the same working principle and with the components as industrial percolators, based on several articles and scientific books on extraction (Pramparo et al., 2002; Singh, 2008; Wijesekera, 2017). The system works by pumping the heated solvent from the collecting vessel into the showerhead and running it through the percolator chamber where it combines with the plant matter, thus extracting solutes as it percolates down. The solvent is then recirculated until an equilibrium concentration is reached.
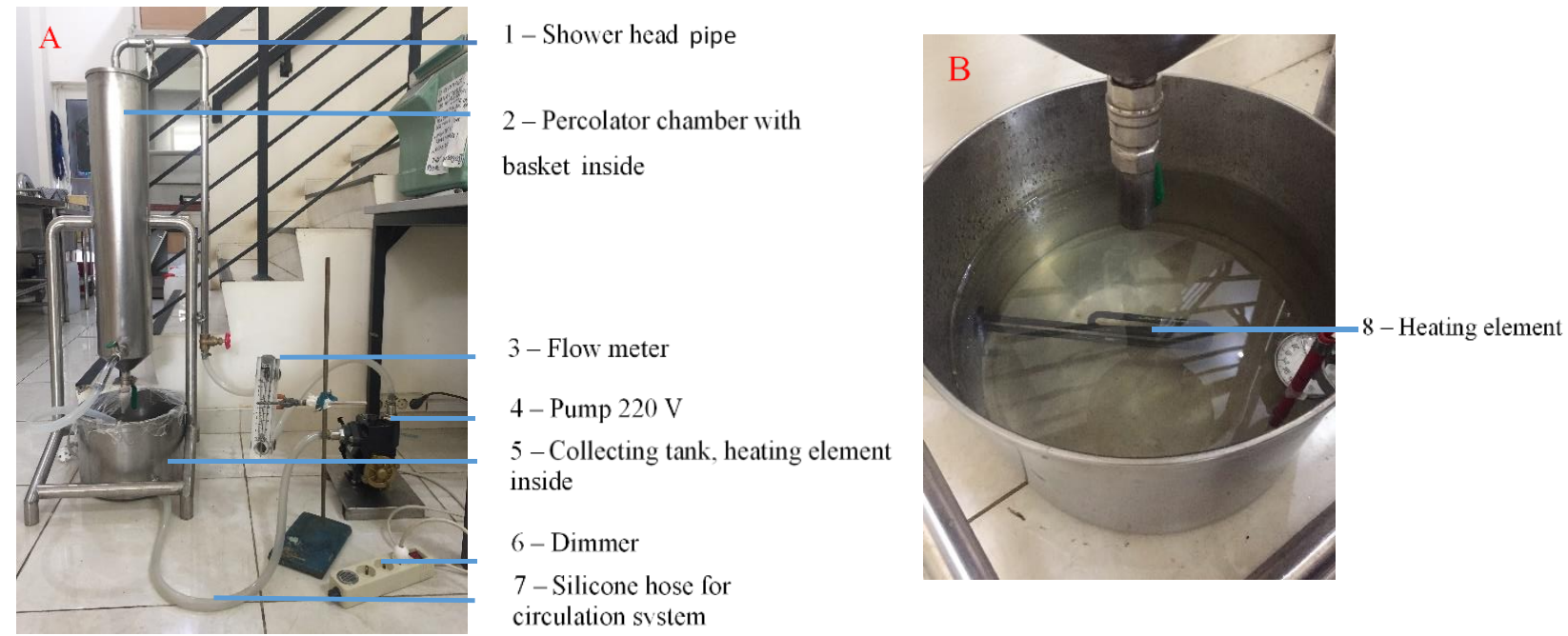

Figure 1 Percolator equipment: (A) percolator chamber; (B) collecting tank

Other important adaptations included the use of a basket with a diameter sieve size of $1 \mathrm{~mm}$ to aid the removal of the extracted plant matter. This size was based on a typical industrial raw material size, which ranges between 1 and $3 \mathrm{~mm}$. The collecting tank or solvent vessel was attached to a heating element to achieve an extraction temperature of $70^{\circ} \mathrm{C}$. A showerhead was utilized to ensure the even distribution of the solvent through the sample. Lastly, the solvent was circulated to exhaust the plant matter as much as possible and achieve a saturated extract. Circulation was utilized to enhance the mass transfer rate, thus reducing the time needed to reach equilibrium.

\subsection{Laboratory Scale Extraction}

At the beginning of this study, in order to enable the comparison between upscaled extractions at the pilot scale to those conducted at the laboratory scale, the lemongrass extraction followed the methods suggested by previous studies, as explained above in the methodology section. Table 1 presents the AGI activity of each of the extracts obtained in this step. 
Table 1 AGI activity of lemongrass extracts obtained at laboratory scale extraction

\begin{tabular}{ccccc}
\hline $\begin{array}{c}\text { Dried } \\
\text { lemongrass }(\mathrm{g})\end{array}$ & $\begin{array}{c}\text { Distilled } \\
\text { water }(\mathrm{mL})\end{array}$ & Concentration $(\mathrm{g} / \mathrm{mL})$ & $\begin{array}{c}\text { Extraction yield } \\
(\%)\end{array}$ & IC $_{50}(\mathrm{ppm})$ \\
\hline 5.00 & 100 & $0.01225 \pm 0.00095$ & $27.30 \pm 2.13^{\mathrm{a}}$ & $\begin{array}{c}12,054.95 \pm \\
468.06^{\mathrm{d}}\end{array}$ \\
\hline 10.00 & 200 & $0.01475 \pm 0.0021$ & $32.87 \pm 4.59^{\mathrm{ab}}$ & $\begin{array}{c}15,717.55 \pm \\
537.93^{\mathrm{c}}\end{array}$ \\
\hline 15.00 & 300 & $0.01767 \pm 0.00058$ & $39.36 \pm 1.29^{\mathrm{b}}$ & $\begin{array}{c}15,808.30 \pm \\
106.37 \mathrm{c}\end{array}$ \\
\hline
\end{tabular}

Different letters in the same column indicate a significant difference at $P \leq 0.05$

Applying the same optimized extraction method from previous studies, the extraction yield for $5 \mathrm{~g}$ of dried lemongrass to $100 \mathrm{~mL}$ of distilled water was found to be $27.30 \pm 2.13 \%$. This was the baseline for the percolation extraction method. The AGI IC 50 obtained from this extraction was $12,054.95 \mathrm{ppm}$, so the maceration extraction was also scaled up using scale factors of 2 and 3, resulting in 10 and $15 \mathrm{~g}$ increases in sample quantity, respectively, under the same conditions. The results show that increasing the sample quantity also increased the extraction yield and $\mathrm{IC}_{50}$. Conducting a one-way ANOVA analysis, at $\alpha=0.05$ the test revealed that, with the increase of sample quantity, there was a highly significant difference in the extraction yield $(P=0.0035)$. A $t$-test analysis conducted to identify which scale factors were significantly different from each other indicated that a significant difference of $\alpha=0.05$ occurred between the scale factors of 1 and $3(P=0.00035)$.

\subsection{Lemongrass Extraction at Pilot Scale}

The result of the laboratory-scale extraction confirmed that increasing the amount of the sample affects the AGI activity of the extract. Hence, any attempt to commercialize the production of lemongrass extract must start with a study of the applications of different types of equipment, ideally using a typical industrial percolator. In order to identify the optimal conditions for extraction using the percolator described above, two experiments were conducted to study the effects of implementing maceration treatment prior to percolation and of using different solvent flow rates.

\subsubsection{Maceration prior to percolation}

Figure 2 illustrates the extraction yield comparison between laboratory-scale extraction and percolation extraction, conducted with and without a preceding maceration step. The results showed that using a percolator significantly increased the yield of the extraction compared to lab-scale extraction. This was because the pilot-scale equipment used had different dimensions and was made from different material (metal instead of glass), which may have improved performance due to metal being better at transferring heat (Rudjito, 2017) and thus enabling more solutes to be extracted. Furthermore, based on geometrical study of a heat transfer, rectangular and cylindrical shapes are more efficient at transferring heat than pyramids or cones because they have smaller wake regions (Yousif and Jassim, 2010).

The results of the final extraction yield and AGI activity incorporating maceration prior to extraction and without maceration are presented in Table 2. The overall extraction yield curve is shown in Figure 3. The optimized laboratory maceration extraction yield used as a baseline was $27.30 \pm 2.13 \%$ (grams soluble solids/grams dried sample). 


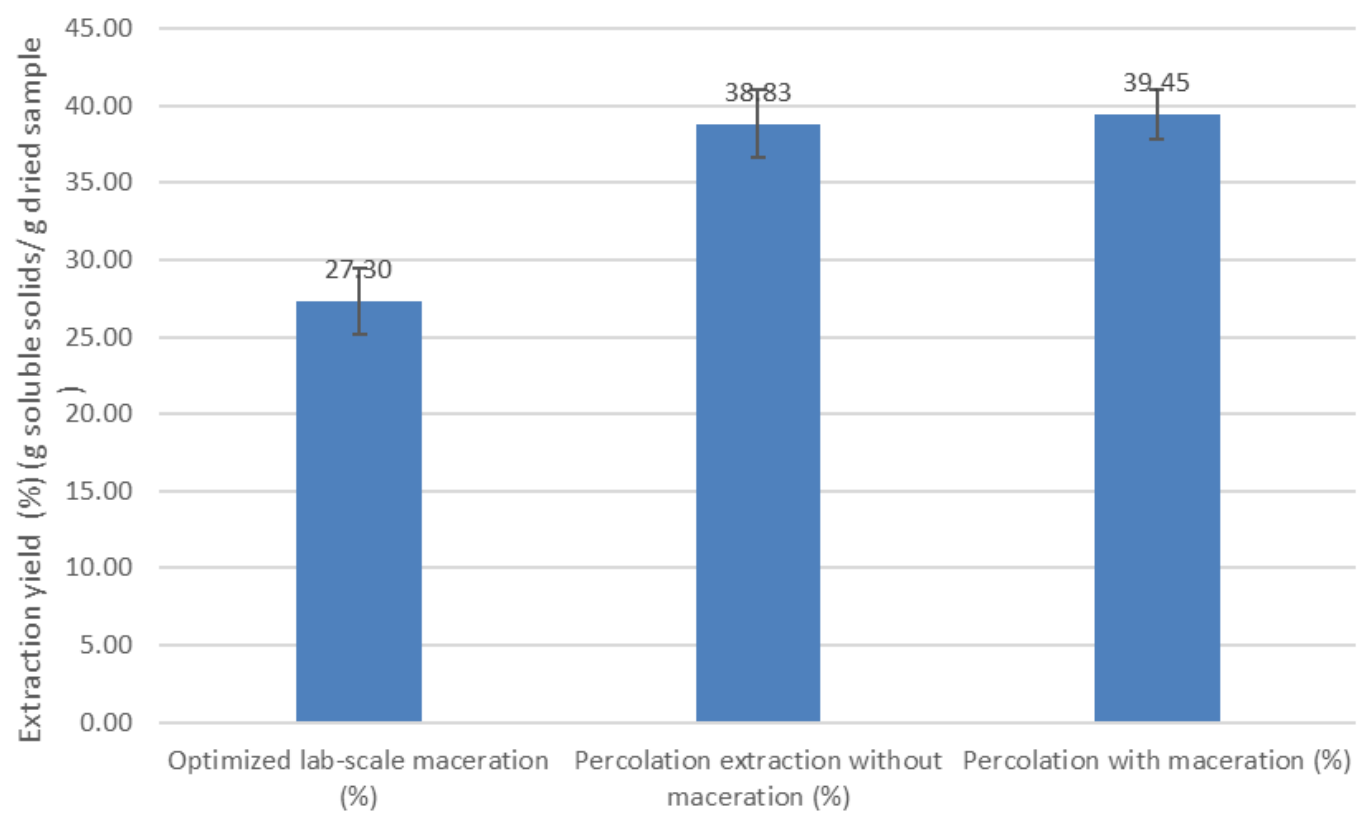

Figure 2 Comparison of extraction yields produced by laboratory-scale extraction and percolation

Table 2 The results for the optimization of maceration treatment

\begin{tabular}{lccc}
\hline \multicolumn{1}{c}{ Treatments } & $\begin{array}{c}\text { Final extraction } \\
\text { yield (\%) }\end{array}$ & AGI IC $_{50}(\mathrm{ppm})$ & $\begin{array}{c}\text { Ln rate of extraction } \\
\text { yield (\% min }\end{array}$ \\
\hline With maceration & $39.45 \pm 1.59^{\mathrm{a}}$ & $14.518 .01 \pm 580.75^{\mathrm{b}}$ & 0.0144 \\
Without maceration & $38.83 \pm 2.17^{\mathrm{a}}$ & $16.407 .23 \pm 3.83^{\mathrm{b}}$ & 0.0137 \\
\hline
\end{tabular}

Different letters in the same column indicate a significant difference at $P \leq 0.05$

The results presented in Table 2 indicate that the final extraction yield for the process with maceration and without maceration differed only slightly, with values of $39.45 \pm 1.59 \%$ and $38.83 \pm 2.17 \%$, respectively. A $t$-test was also conducted, which showed that this difference was not significant $(P=0.74)$. This means that maceration had no effect on obtaining a higher extraction yield. According to one study, increasing maceration time increases the yield of phenolic compounds and may result in better AGI activity (Kocabey et al., 2016). In this case, the AGI IC 50 of both extracts produced with and without maceration have no significant difference. However, in order to produce a dramatic effect, the maceration process should last hours or even days; in this experiment it lasted only for 1 hour, so it had no significant effect on the extract's AGI activity.

Regardless of the maceration time, one thing proven by this experiment was that the extraction yield produced by percolation surpassed that obtained using the optimized laboratory maceration method, which acted as the baseline performance to be achieved. This indicates that percolation extraction performs better in terms of yield.

Although maceration did not affect the final extraction yield or its AGI activity, it did influence the rate of extraction. The graph presented in Figure 3 shows that the process with maceration required only 20 minutes to achieve the same equilibrium concentration as that of that without maceration achieved in 40-50 minutes. This was supported by the logarithmic rate of extraction presented in Table 2, with a value of $0.0144 \% \mathrm{~min}-1$ for maceration compared to $0.0137 \%$ min- 1 without maceration. Therefore, percolation following maceration is considered to be the optimum treatment, because it achieves the same performance in less time. 


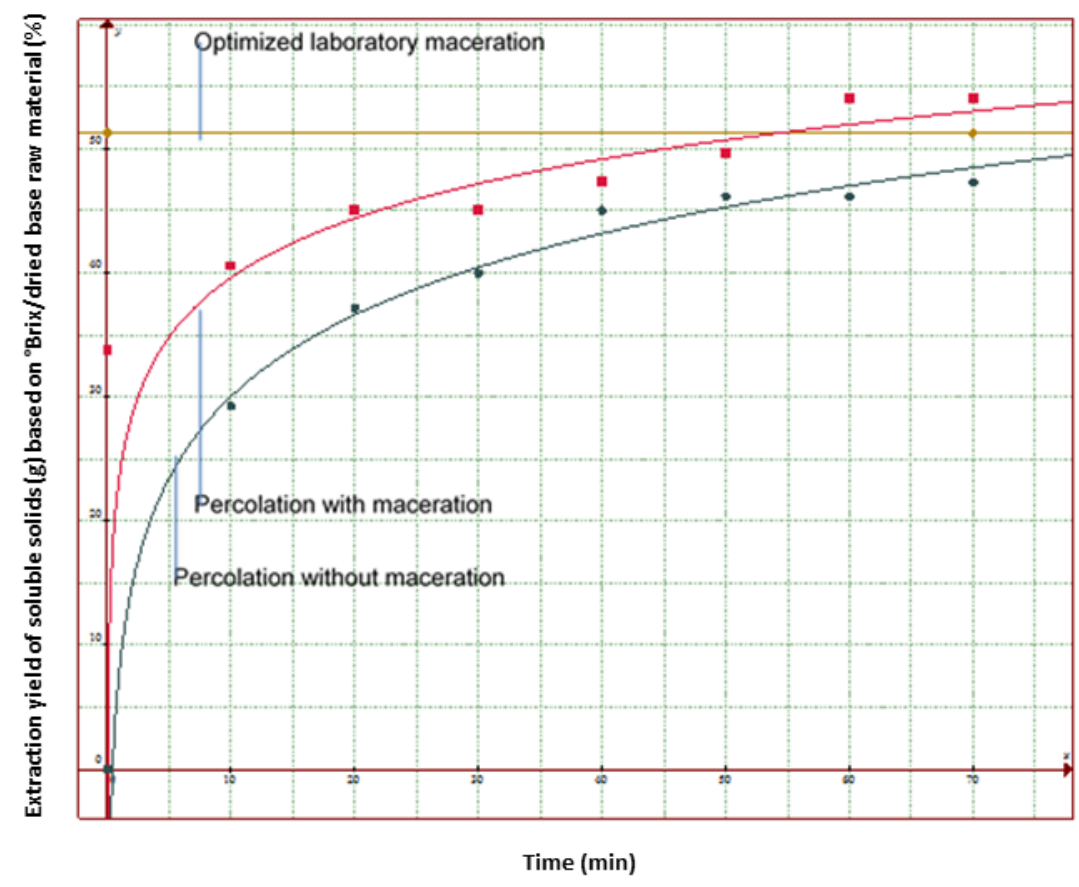

Figure 3 Overall extraction yield curve graph for the yields produced with and without maceration

\subsubsection{Flow rate variations}

The different flow rates calculated in this experiment were determined based on the pump capacity used in the percolation system. Flow rates of $63.09 \mathrm{~cm}^{3} \mathrm{~s}^{-1}, 96.64 \mathrm{~cm}^{3} \mathrm{~s}^{-1}$, $126.20 \mathrm{~cm}^{3} \mathrm{~s}^{-1}$, and $189.30 \mathrm{~cm}^{3} \mathrm{~s}^{-1}$ are equal to $1.0,1.5,2.0$ and $3.0 \mathrm{gal} / \mathrm{min}$, respectively. The results of the final extraction yield and AGI activity incorporating different flow rates are presented in Table 3 and the overall extraction yield curve is shown in Figure 4.

Table 3 Results of the optimization of flow rate variations

\begin{tabular}{ccccc}
\hline No. & $\begin{array}{c}\text { Flow rate } \\
\left(\mathrm{cm}^{3} \mathrm{~s}^{-1}\right)\end{array}$ & $\begin{array}{c}\text { Final Extraction Yield } \\
(\%)\end{array}$ & $\begin{array}{c}\text { Rate of extraction } \\
\text { yield }\left(\% \mathrm{~min}^{-1}\right)\end{array}$ & $\begin{array}{c}\text { AGI inhibition } \\
(\%)\end{array}$ \\
\hline I. & 63.09 & $39.45 \pm 1.59^{\mathrm{a}}$ & $0.24 \pm 0.023^{\mathrm{c}}$ & $44.04 \pm 0.20^{\mathrm{b}}$ \\
II. & 94.64 & $39.31 \pm 1.59^{\mathrm{a}}$ & $0.34 \pm 0.023^{\mathrm{c}}$ & $49.89 \pm 3.48^{\mathrm{b}}$ \\
III. & 126.20 & $42.53 \pm 0.00^{\mathrm{a}}$ & $0.29 \pm 0.00^{\mathrm{c}}$ & $47.36 \pm 0.31^{\mathrm{b}}$ \\
IV. & 189.30 & $40.29 \pm 0.00^{\mathrm{a}}$ & $0.16 \pm 0.00^{\mathrm{d}}$ & $34.27 \pm 7.95^{\mathrm{b}}$ \\
\hline
\end{tabular}

The different letters in the same column indicate a significant difference at $P \leq 0.05$

The results presented in Table 3 show that flow rate variations had no influence on extraction yield or AGI activity $(P=0.13$ and 0.078 , respectively). However, in terms of extraction yield, the flow rate of $94.64 \mathrm{~cm}^{3} \mathrm{~s}^{-1}$ was shown to provide the highest rate of change, with a value of $0.34 \pm 0.023 \% \mathrm{~min}^{-1}$. This is also shown in Figure 4 : using a flow rate of $94.64 \mathrm{~cm}^{3} \mathrm{~s}^{-1}$, equilibrium concentration was achieved in 50 minutes, while the rest of the variations required 60 minutes and 70 minutes. Two flow rate variations, $126.20 \mathrm{~cm}^{3} \mathrm{~s}^{-}$ 1and $189.30 \mathrm{~cm}^{3} \mathrm{~s}^{-1}$, failed to reach equilibrium concentration during the observation time, which can be explained by the different amounts of time during which the solvent was percolated and the solvent was in contact with the plant matter. 


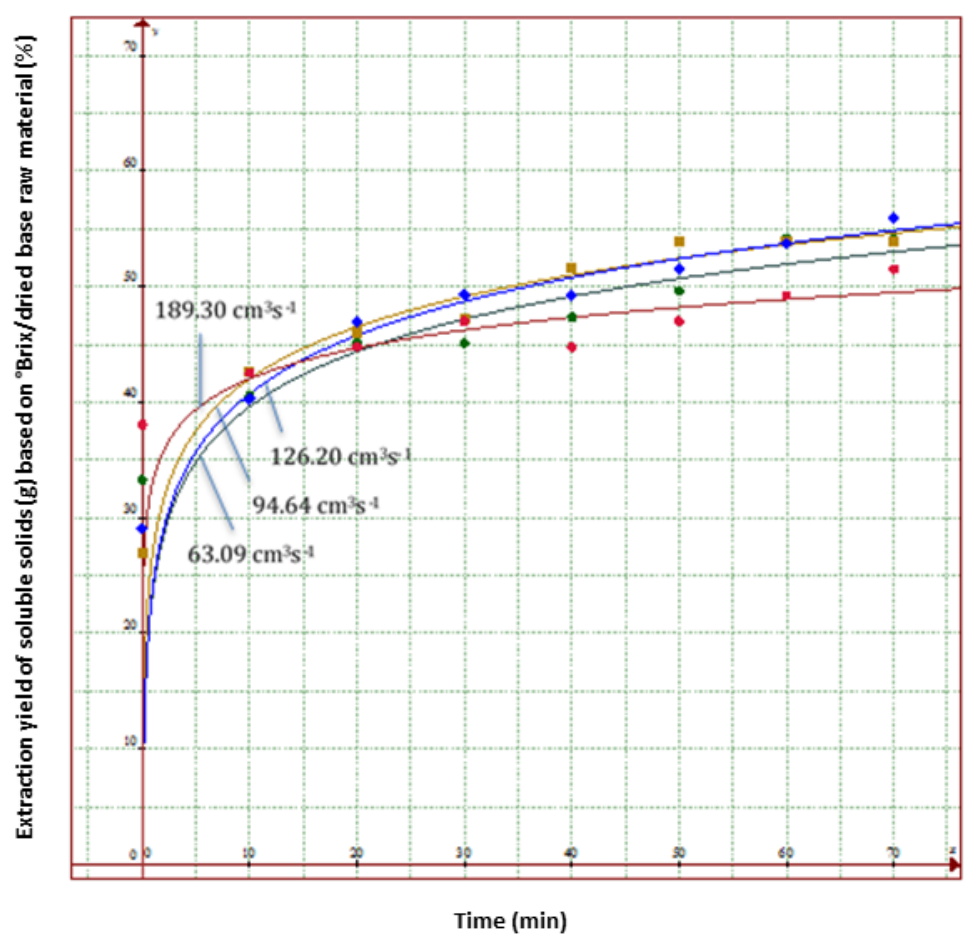

Figure 4 Overall extraction yield curve of optimization flow rate variations

For the lowest flow rate, $63.09 \mathrm{~cm}^{3} \mathrm{~s}^{-1}$, the solvent moved relatively slowly, resulting in less circulation and lower mass transfer. This in turn resulted in the concentration taking longer to reach equilibrium, although the contact or residence time was still sufficient to reached the same equilibrium extraction yield as the optimum condition. The flow rates of $126.2 \mathrm{~cm}^{3} \mathrm{~s}^{-1}$ and $189.3 \mathrm{~cm}^{3} \mathrm{~s}^{-1}$ caused the solvent to move too fast, leaving little time for the solvent to remain in contact with the plant matter; the extractable matter was thus simply bypassed, causing insufficient loading and deviation during the equilibrium concentration time (Kumoro and Hasan, 2007), as shown in Figure 4. This resulted an incomplete saturation of solutes in the solvent, and thus a longer equilibrium point and lower rate of extraction yield. As the flow rate variation of $94.64 \mathrm{~cm}^{3} \mathrm{~s}^{-1}$ achieved the same performance as other flow variations in less time, it was determined to be the optimum flow rate.

\subsection{The Effect of Upscaling the Process on AGI Activity}

The effects of increasing the sample quantity on AGI activity and extraction yields are presented in Table 4. The final extraction yields achieved are similar from one sample size to another and were shown to be insignificantly different $(P=0.91)$. The AGI activity of the extract resulting from sample quantity of $300 \mathrm{~g}$ was found to be $49.89 \pm 3.476 \%$, corresponding to a concentration of $0.018 \pm 0.0007 \mathrm{~g} / \mathrm{mL}$ or $18,000 \mathrm{ppm}$. The same extract concentration resulting from a laboratory-scale process using $5 \mathrm{~g}$ of the sample (with $\mathrm{IC}_{50}$ of $12,054.95 \pm 468.06$ ) had an AGI activity of approximately $70 \%$. This reflects a significant decrease of AGI when switching to percolation.

Table 5 summarizes the results of same circulation number method in bold, which was used for the upscaled approach. The theoretical equilibrium time for a sample quantity of $400 \mathrm{~g}$ was determined to be 66.67 minutes, indicating that $400 \mathrm{~g}$ of sample matter required 66.67 minutes to achieve equilibrium concentration. With the same number of circulations, a sample quantity of $500 \mathrm{~g}$ required 83.34 minutes to reach equilibrium concentration. These results were compared to experimental results (plotted in Figure 5) and indicated 
that, experimentally, a sample mass of $400 \mathrm{~g}$ achieved equilibrium concentration at exactly 66 minutes and $500 \mathrm{~g}$ at 80 minutes. This demonstrates that the same circulation number approach is applicable for upscaling.

Table 4 The effect of increased sample quantity on extraction yields and AGI activity

\begin{tabular}{ccccc}
\hline $\begin{array}{c}\text { Sample } \\
\text { Quantity }\end{array}$ & $\begin{array}{c}\text { Initial extraction } \\
\text { yield after } \\
\text { maceration (\%) }\end{array}$ & $\begin{array}{c}\text { Final } \\
\text { extraction } \\
\text { yield (\%) }\end{array}$ & $\begin{array}{c}\text { Concentration } \\
(\mathrm{g} / \mathrm{mL})\end{array}$ & $\begin{array}{c}\text { AGI activity of the } \\
\text { same concentration } \\
(\%)\end{array}$ \\
\hline 300 & $14.89 \pm 1.26$ & $39.45 \pm 1.59 \mathrm{a}$ & $0.018 \pm 0.0007$ & $49.89 \pm 3.476^{\mathrm{a}}$ \\
400.03 & $28.05 \pm 1.59$ & $39.27 \pm 1.59 \mathrm{a}$ & $0.0175 \pm 0.0007$ & $27.79 \pm 3.74 \mathrm{~b}$ \\
500.03 & $27.59 \pm 1.70$ & $38.39 \pm 3.39 \mathrm{a}$ & $0.016 \pm 0.0014$ & $8.54 \pm 12.07 \mathrm{~b}$ \\
\hline
\end{tabular}

Different letters in the same column indicate a significant difference at $P \leq 0.05$

Table 5 The calculated time and equilibrium time of extraction based on the same circulation method

\begin{tabular}{ccccccc}
\hline $\begin{array}{c}\text { Mass } \\
(\mathrm{g})\end{array}$ & $\begin{array}{c}\text { Volume } \\
\text { of solvent } \\
\left(\mathrm{cm}^{3}\right)\end{array}$ & $\begin{array}{c}\text { Optimum } \\
\text { flow rate } \\
\left(\mathrm{cm}^{3} \mathrm{~s}^{-1}\right)\end{array}$ & $\begin{array}{c}\text { Number of } \\
\text { circulations }\end{array}$ & $\begin{array}{c}\text { Time of } \\
\text { extraction } \\
(\mathrm{min})\end{array}$ & $\begin{array}{c}\text { Number of } \\
\text { equilibrium } \\
\text { circulations }\end{array}$ & $\begin{array}{c}\text { Theoretical } \\
\text { Equilibrium } \\
\text { time (min) }\end{array}$ \\
\hline 300.03 & 6,000 & & & 70 & & 50 \\
400.03 & 8,000 & 94.64 & 66.243 & 93.33 & 47.32 & 66.67 \\
500.03 & 10,000 & & & 116.67 & & 83.34 \\
\hline
\end{tabular}

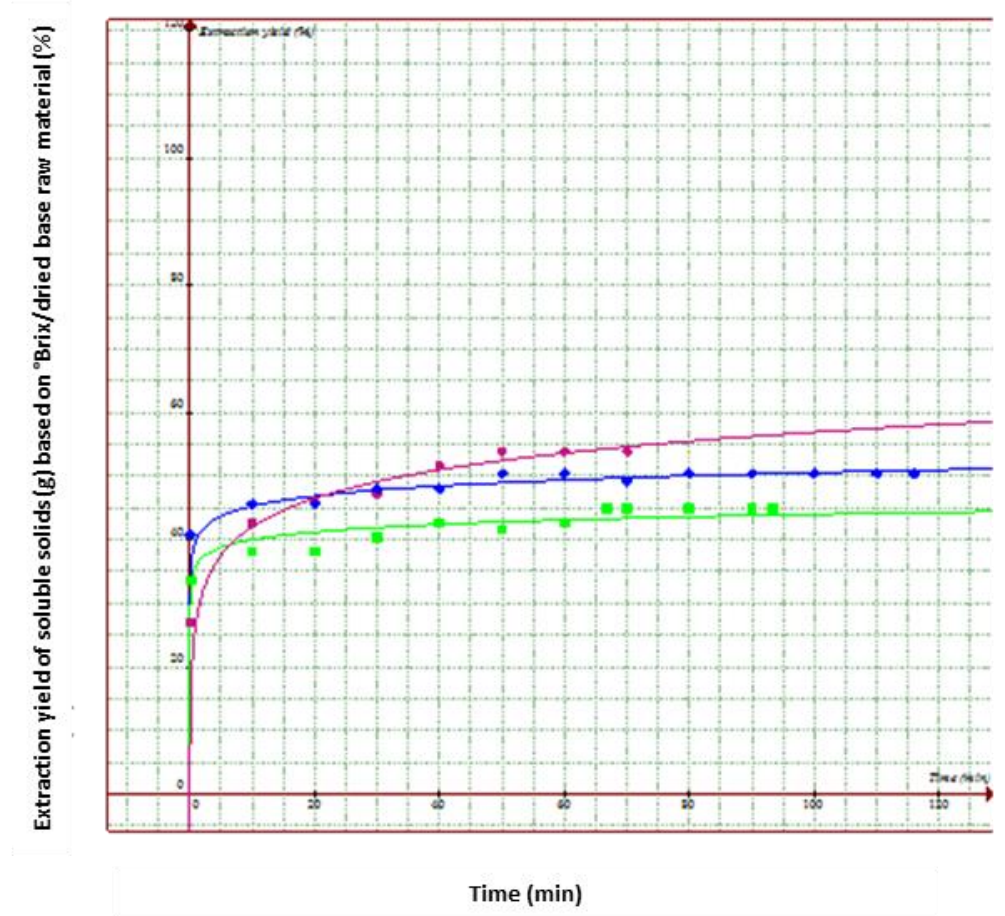

Figure 5 Overall extraction yield curve of upscaling

Increasing the sample quantity decreased AGI activity significantly ( $p$-value $=0.026$ and 0.048 for 400 and $500 \mathrm{~g}$, respectively). This reduction may have been caused by the reduction of porosity in the sample bed as the sample quantity increased. Once the plant 
matter is macerated it can choke the tube leading to the collecting tank, which hinders the solvent's penetration of the bed of wet solid. This in turn causes the solvent to form preferential pathways or channels, which causes further insufficient solute diffusion from the inner plant cells where phytochemicals are usually found-in this case extraction only occurs on the sides or outer parts of the plants (del Valle et al., 2004; Fernández-Ponce et al., 2016). This in turn may reduce the amount of AGI compounds to be extracted.

Having the same extraction yield did not always produce the same AGI inhibition activity because not all of the soluble solids extracted are AGI. Even those compounds that were extracted had different inhibitory properties. For example, Oboh et al. (2015) showed that caffeic acid and chlorogenic acid, two compounds found in lemongrass that contribute to AGI activities, have different AGI capabilities and that caffeic acid is more effective. As this study examined only the whole AGI performance, this could also be the reason why AGI activity was varied in the results. Therefore, this result indicates that increasing the sample quantity decreases AGI activities.

\section{Conclusions}

In conclusion, the upscaling of Cymbopogon citratus (lemongrass) extraction revealed that AGI activity decreased as the sample quantity was increased. This decrease in AGI activity was also found when a percolator was applied in a pilot scale, although the extraction yield increased significantly. In order to maintain optimum AGI activity, the maximum sample quantity used in the percolator designed for this study was $300 \mathrm{~g}$, and the implementation of an initial maceration treatment is suggested. In order to further expand the operating capacity of such a process, modification of the operating conditions must be considered; such a change might require improving the solvent flowing profile through the sample bed in the percolator.

\section{Acknowledgements}

The author would like to thank the Ministry of Research, Technology, and Higher Education of the Republic of Indonesia (Ristekdikti) for funding this project (contract nos. 209/M/KPT/2018; 7/E/KPT/2019 and AGMT/REC/A0010/III/2019). The help and support from lecturers and laboratory assistants in the Faculty of Life Sciences and Technology of Swiss German University are also acknowledged.

\section{References}

Adiyoga, G.H., Kartawiria, I.S., Gunawan-Puteri, M.D., 2015. Ready to Drink Medicinal Beverages from Indonesian Plant with High Alpha-glucosidase Inhibitory Activity. Bachelor's Thesis, Swiss German University, Tangerang, Indonesia. Available Online at: http://library.sgu.ac.id/index.php?p=show_detail\&id=28654\&keywords=herdiazto. Accessed November 3, 2019

Balakrishna, T., Vidyadhara, S., Sasidhar, R., Ruchita, B., Prathyusha, E., 2016. Review on Extraction Techniques. Indo American Journal of Pharmaceutical Sciences, Volume 3(8), pp. 880-891

Basu, S., Yudkin, J. S., Kehlenbrink, S., Davies, J.I., Wild, S.H., Lipska, K.J., Sussman J.B., Beran, D., 2019. Estimation of Global Insulin Use for Type 2 Diabetes, 2018-30: A Microsimulation Analysis. The Lancet Diabetes \& Endocrinology, Volume 7(1), pp. 2533

Cechinel-Filho, V., 2012. Plant Bioactives and Drug Discovery: Principles, Practice, and Perspectives. Hoboken, New Jersey: John Wiley \& Sons 
Chow, C. K., Ramasundarahettige, C., Hu, W., AlHabib, K.F., Avezum Jr, A., Cheng ,X., Chifamba ,J., Dagenais, G., Dans, A., Egbujie, B.A., Gupta, R., Iqbal, R., Ismail, N., Keskinler M.V., Khatib, R., Kruger, L., Kumar, R., Lanas, F., Lear, S., Lopez-Jaramillo, P., McKee, M., Mohammadifard, N., Mohan, V., Mony, P., Orlandini, A., Rosengren, A., Vijayakumar, K., Wei, L., Yeates, K., Yusoff, K., Yusuf, R., Yusufali, A., Zatonska, K., Zhou, Y., Islam, S., Corsi, D., Rangarajan, S., Teo, K., Gerstein, H.C., Yusuf, S., 2018. Availability and Affordability of Essential Medicines for Diabetes across High-income, Middle-income, and Lowincome Countries: A Prospective Epidemiological Study. The Lancet Diabetes and Endocrinology, Volume 6(10), pp. 798-808

del Valle, J.M., Rivera, O., Mattea, M., Ruetsch, L., Daghero, J., Flores, A., 2004. Supercritical $\mathrm{CO}_{2}$ Processing of Pretreated Rosehip Seeds: Effect of Process Scale on Oil Extraction Kinetics. Journal of Supercritical Fluids, Volume 31(2), pp. 159-174

Dewi, D.S., Irfoni, A.R., Rahman, A., 2017. Kansei Engineering Approach for Designing a Selfmonitoring Blood Glucose Application. International Journal of Technology, Volume 8(2), pp. 272-282

Fernández-Ponce, M.T., Parjikolaei, B.R., Lari, H.N., Casas, L., Mantell, C., de la Ossa, E.J.M., 2016. Pilot-plant Scale Extraction of Phenolic Compounds from Mango Leaves using Different Green Techniques: Kinetic and Scale Up Study. Chemical Engineering Journal, Volume 299, pp. 420-430

Gunawan-Puteri, M., Josopandojo, B.M., Adiyoga, G.H., Kartawiria, I., Widiputri, D.I., 2016. Development of Food Ingredients with Antidiabetic Activities from Lemongrass (Cymbopogon citratus). In: Integrated Sci-Tech: The Interdisciplinary Research Approach, Volume 2, Sukmana, I. (ed.). Lampung, Indonesia: Research Institute and Community Service of University of Lampung, pp. 55-61

Institute for Quality and Efficiency in Health Care, 2018. Medication for Type 2 Diabetes. Institute for Quality and Efficiency in Health Care (IQWiG). Available Online at: https://www.ncbi.nlm.nih.gov/books/NBK279506/?report=classic. Accessed on November 3, 2019

Jones, M., Fosbery, R., Gregory, J., Taylor, D., 2012. Cambridge International AS and A Level Biology. $4^{\text {th }}$ Edition. Cambridge, United Kingdom: Cambridge University Press

Kang, M.-G., Yi, S.-H., Lee, J.-S., 2013. Production and Characterization of a New $\alpha-$ Glucosidase Inhibitory Peptide from Aspergillus oryzae N159-1. Mycobiology. Korean Society of Mycology, Volume 41(3), pp. 149-154

Khalili, M., Fathi, H., Ebrahimzadeh, M.A., 2016. Antioxidant Activity of Bulbs and Aerial Parts of Crocus caspius, Impact of Extraction Methods. Pakistan Journal of Pharmaceutical Sciences, Volume 29(3), pp. 773-777

Kocabey, N., Yilmaztekin, M., Hayaloglu, A.A., 2016. Effect of Maceration Duration on Physicochemical Characteristics, Organic Acid, Phenolic Compounds and Antioxidant Activity of Red Wine from Vitis vinifera L. Karaoglan. Journal of Food Science and Technology, Volume 53(9), pp. 3557-3565

Kumar, S., Narwal, S., Kumar, V., Prakash, O., 2011. $\alpha$-glucosidase Inhibitors from Plants: A Natural Approach to Treat Diabetes. Pharmacognosy Reviews, Volume 5(9), pp. 19-29

Kumoro, A.C., Hasan, M., 2007. Supercritical Carbon Dioxide Extraction of Andrographolide from Andrographis paniculata: Effect of the Solvent Flow Rate, Pressure, and Temperature. Chinese Journal of Chemical Engineering, Volume 15(6), pp. 877-883

Mulia, K., Krisanti, E.A., Maulana, T., 2015. Selective Polarity-guided Extraction and Purification of Acetogenins in Annona muricata L. leaves. International Journal of Technology, Volume 6(7), pp. 1221-1227 
Oboh, G., Agunloye, O.M., Adefegha, S.A., Akinyemi, A.J., Ademiluyi, A.O., 2015. Caffeic and Chlorogenic Acids Inhibit Key Enzymes Linked to Type 2 Diabetes (in vitro): A Comparative Study. Journal of Basic and Clinical Physiology and Pharmacology. Volume 26(2), pp. 165-170

Pramparo, M., Gregory, S., Mattea, M., 2002. Immersion vs. Percolation in the Extraction of Oil from Oleaginous Seeds. Journal of the American Oil Chemists'Society, Volume 79(10), pp. 955-960

Rahman, M., Hossain, S., Rahaman, A., Fatima, N., Nahar, T., Uddin, B., Basunia, M.A., 2013. Antioxidant Activity of Centella asiatica (Linn.) Urban: Impact of Extraction Solvent Polarity. Journal of Pharmacognosy and Phytochemistry, Volume 1(6), pp. 27-32

Rudjito, R.C., 2017. Pilot Scale Process for Polysaccharide Extraction and Fractionation from Cereal By-products. KTH VETENSKAP OCH KONST. Available Online at: http://www.divaportal.se/smash/get/diva2:1145635/FULLTEXT01.pdf

Santoso, F., Winarno, J., Gunawan-Puteri, M.D.P.T., 2018. Application of Lemongrass (Cymbopogon citratus) as a Functional Food Ingredient with Alpha-Glucosidase Inhibitory Activity. Advances in Engineering Research, Volume 172, pp. 205-209. Available Online at: https://www.atlantis-press.com/proceedings/fanres-18/ 25907139 Accessed January 8, 2019

Singh, J., 2008. Maceration, Percolation and Infusion Techniques for the Extraction of Medicinal and Aromatic Plants. In: Extraction Technologies for Medicinal and Aromatic Plants. Edited by S. S. Handa et al. Trieste: International Centre for Science and High Technology

Suryanegara, M., Nugraha, I.G.D., Adhi, B.A., Lubis, M.F., Putra, M.R.E., 2015. The Local Innovation Perspective: Development of Mobile-Herbal Service for Indonesia's Mobile Cellular Market. International Journal of Technology, Volume 6(2), pp. 109-120

Widiputri, D.I., Mariana, N., Josopandojo, B., Gunawan-Puteri, M., Kartawiria, I.S., 2017. Effect of Pre-treatment Processes and Stability Testing of Lemongrass (Cymbopogon citratus) Extract on $\alpha$-Glucosidase Inhibitor (AGI) and $\alpha$-Amylase Inhibitor (AAI) Activities. In: Proceeding of International Postgraduate Symposium on Food, Agriculture and Biotechnology (IPSFAB) 2017. doi: 10.10.14457/MSU.res.2017.22

Widiputri, D.I., Gunawan-Puteri, M.D., Kartawiria, I.S., 2019. Benchmarking Study of Cymbopogon citratus and C. nardus for Its Development of Functional Food Ingredient for Anti-diabetic Treatment. ICONIET Proceeding, Volume 2(2), pp. 109-114

Wijesekera, R.O.B., 2017. Technologies for the Processing of Medicinal Plants. The Medicinal Plant Industry. New York. NY: Taylor and Francis

World Health Organization (WHO), 2018. Diabetes. Available Online at: https://www.who.int/news-room/fact-sheets/detail/diabetes. Accessed on November 3, 2019

Yousif, A.H., Jassim, K.D., 2010. Effect of Cylinder Shape on Heat Transfer and Fluid Flow. AlQadisiya Journal for Engineering Sciences, Volume 3(3), pp. 1-11

Zhou, H., Luo, D., Gholam Hosseini, H., Li, Z., He, J., 2017. Identification of Chinese Herbal Medicines with Electronic Nose Technology: Applications and Challenges. Sensors, Volume 17(5), pp. 1-21 